\title{
先天性の筋力薄弱に基くと思はれる腰椎前彎の一例
}

\section{A Case of Congenital Muscular Lumbar-Lordosis}

\section{日本医科大学整形外科教室（主任 斎藤一男教授）}

丹 保 三 郎

\section{Tan Yasusaburō}

(本諡文の内容は昭和 26 年 11 月第 200 回整形外科 集談全東京地方会に於て発表された）

\section{緒言}

腰櫵前禁は，それ自体としては決して玢しいもので はないが，先天性の筋力薄弱による例は余り報告をみ

い岀である。

私は, 恐らく先天性の筋力蒔弱に时来し, 冻児期よ り次第に増強して遂に高度の腰椎前綃とそれに伴う以 円背湓勢を来たした一症例を経駼したので站に御報告 する。

\section{症例}

12 于の少女, 腰部の変形を主訴として昭和 26 年 7 月 27 日来院した。分啲は正常位軽座であり母乳に より喇青された。雪牙発生は 10 ケ月, 処女起立 1 年 $2-3$ ケ月, 処女步行 1 年半前後。

4 才㥧（昭 18），躀いたり転んだりし易いのに，又 馸けると左足が外方へ弧を描くのに気付いている。原 因と考党られるものはなかつた。同年 10 月 1 日本学 整形外形外来を訪れて諸検查の末，骨には異常はない と王はれ酒側大腿の煺正長術を行つている。当時漱く

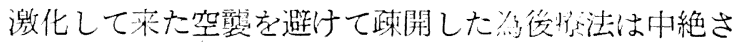
れてしまつた，等部の突出は次第に目立つ様になり 「お坐り」も出米ないので， 7 月末 8 年振りに当科を 訪水来たつた。

父と父の姉 (伯母) に軽度の所謂出民を認める。

既往症 生後50日で百日咳肺焱䍜患。其の他は麻

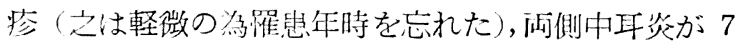
才, 口内炎 13 丮。ッ反応は陸性。

来院侍, 虫者は次の様に云つている。即ち, 䡅く起 つていると䦌滕に同程度の悀みと疲学を覚える。長く 続けると, この外には, 左の足尖足底, 右の足尖足底 に，この順の强さで痛みを訴光る。一般に右に比べて 左半身が早く且强く瘦狆晃いと。試又に日本式静坐を 行はせると, 闻下肢外側及び大腿上面に疲学感と旁引 痛があり，等畄と下眼間には二横指を插入することが
出来た。仰卧しても腰部の前繂は減じない。

三輪氏の方法により撮影計測された春柱レ線像は， 略同年度女生徒との対比に於て, 矢状面では表 1,2 の如くなる。同じく前額面について観察すると，第 3 -4-5-6 胸椎を頂点とする右側䅉性姿勢が認められ る。脊椎の捻転は著明でない。

レントゲン像による知状面測定値（一）

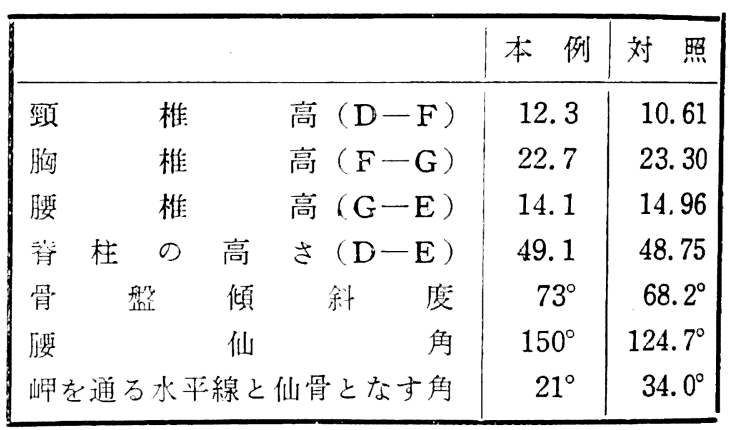

レントゲン像による矢状面測定优（二）

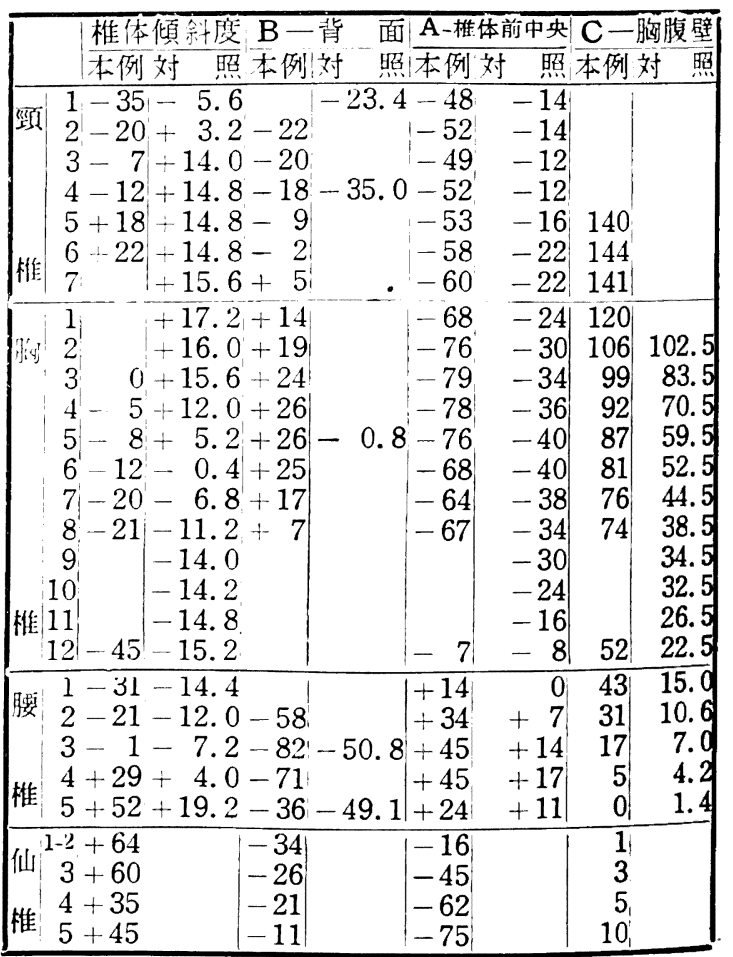




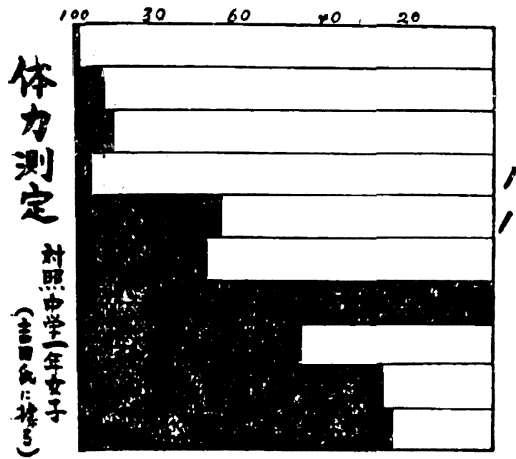

54.8 比尘高 19.4 方上的宛田 19.0 龙上腕圈 110. D-2儿俰数 1340 肺活量 1.14 跳 力

O. 踏垂盛臂 28 背䈞 5 方握力 4 左握力

患者の体力については図汇示された通りで，このグ ラフは吉田氏の測定值（中学 1 年女子）に対する百分 率で示されている。

筋の電気的診断については, 電気変性反応は菏側共 飞陰性であり，左右の差異は認められなかつた。筋ク ロナキシーは概して右に比べると右側筋が稍と 6 の值 が高く, 久一般に恃左右共化正常值範囲より軽度の延 長をみせている，筋電図では左側が幾分筋力の衰えを 現はしている様に観察された。

筋圧入度試験は弛綏状態と緊張状態の差異が左側で はより小であつた，一般には左右共差異は少い，

其の他, 血液飞は特別な所見なく, 起立性㔻白尿は 陰性であつた，自律神経系の試験成績は正常つ籍囲と 認める。

考案

F. Lange は，小学児童の姿勢中凹仙なる一㴌勢を 分類すべき事を提言しているが，その原因として骨盤 の前方傾斜度を重視し，その過度傾斜法るる股関節屈 伸筋間の平衡破綻を挙げ，特に大腎筋の過伸展による ととを云つている。

本例では，大臂筋の変化は之を証明する事が出来ず 系ろ背筋群の薄弱を稍と著明に認めた。

つまり本症例は，家系にみた如く，ある先天的素目 が内在して更飞全身特に北部筯力の薄弱化が促進さ れ，遂汇高度の骨盤前傾が起つたものと考兄られる。

電気的諸検査の結果は一般沉左は右汇較べて筋力の 劣勢を示しているが，これらは患者訴えに一致し，又 胸椎の側䅴性姿勢の成立とも眮味ある関連を示するの と思はれる。

次起立性蛋白尿の原因関しては，Jehle 以来 諸氏によつて腰部前繜説, 無力性体質説が唱えられて いるが，斎藤教授は 39 名の本症者を含む 13 才の学 童 81 名について長期に亘り精査された結果, 直立位
腰部前戀度の強弱と尿中排沚蛋白量との間には直接的 関係なく他の何等かの因子が主役を演ずるものである 万と結論されている。私の経験例でも㔻白尿は䢒に検 出出来なかつた。

\section{結語}

1）私は先天性の筋力溥弱に原因すると思はれるる高

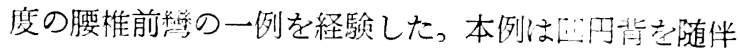
しているが， Lange によればこれは反つて洧なこ とである,

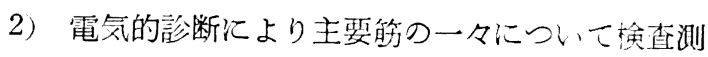
定した結果は， Lange が重視する大等節には荌驽な

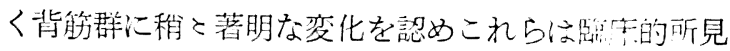
と一致するものである。

3）起立生蛋白尿の成因について現今広！行はれて

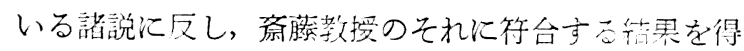
た。

4) 7 月以来隔日に通院せしめ，主として的兽強

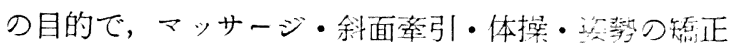
・ワゴスチグミン注射を行ひ，作せて家县に於けるー ッサージ・体操を計画的汇指示して実行させ現在们続 行中であるが, 殊心北筋力, 握力の弐躍的增強齐示し

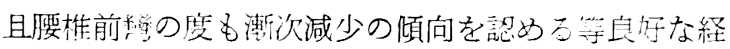
過を辿りつ১ある様に钼察されている。

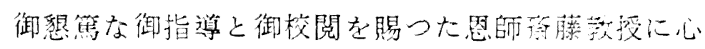

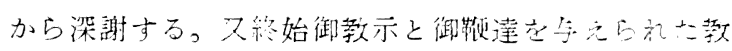
宝諎先㐟に事心感謝の意を表する。

\section{主要 交 献}

1) 稍藤一男: 日整会䞌, 18, 7 号

2) 三斡泰雄: 体育研究, 8,5 号, 6 号

3) 大河内一即: 体育研究, 10, 1号

4) 一>瀬三郎：体育研究， 10,4步

5) 神中正一：整形外科

6) 橋倉一裕: 学校衛生, 21,8 号

7) 伊藤久治：日外会鼓，25回，11号，12 号

8）渡辺林八郎：京府医大誌，32，1号

9) 田原鎮雄：電気診断及治療学

10）時䒠利彦：筋電図の臨床的応用

11）長松英一：関節遇動上引みたる筋子

12) 吉田章信：体力測定

13) Lange u. Spitz : Münch. med. W., Jg. 74 (1927)

14) Lange: Die Haltungsschäden u. die Leibsübungen

15) Hohmann u. Stumpf : Orthopädische gymnastik 